\title{
Morphology regulation in vascular endothelial cells
}

Kiyomi Tsuji-Tamura ${ }^{1,2^{*}}$ and Minetaro Ogawa ${ }^{1}$

\begin{abstract}
Morphological change in endothelial cells is an initial and crucial step in the process of establishing a functional vascular network. Following or associated with differentiation and proliferation, endothelial cells elongate and assemble into linear cord-like vessels, subsequently forming a perfusable vascular tube. In vivo and in vitro studies have begun to outline the underlying genetic and signaling mechanisms behind endothelial cell morphology regulation. This review focuses on the transcription factors and signaling pathways regulating endothelial cell behavior, involved in morphology, during vascular development.
\end{abstract}

Keywords: Vasculature, Endothelial cells, Angiogenesis, Morphology, Elongation

\section{Background}

\section{Vascular system development}

During the earliest stages of embryonic development, vascular formation occurs in connection with blood cell formation (hematopoiesis) $[1,2]$. There are various theories about the origin of endothelial cells, but the mesoderm has been reported to generate an endothelial cell progenitor (angioblast) and a common progenitor of hematopoietic cells and endothelial cells (hemangioblast) [3] (Fig. 1). De novo vascularization, or vasculogenesis, is accomplished by endothelial cells derived from these mesodermal progenitors. During this process, cells form a primitive vessel network that serves as the basis for the mature vascular system [4]. New blood vessels are then formed from pre-existing ones and spread into avascular areas. This process, in which the network of early primitive vessels is expanded, is defined as angiogenesis [5]. Subsequently, vasculature undergoes remodeling in an ordered manner. Initiation of endothelial cell specification into arteries and veins appears to occur before forming structural arteries and veins [6]. Vasculature maturation results when new blood vessels recruit and are linked to vascular smooth muscle cells and pericytes. In addition, a population of endothelial cells

\footnotetext{
*Correspondence: ktamuratsuji@den.hokudai.ac.jp

1 Department of Cell Differentiation, Institute of Molecular Embryology and Genetics, Kumamoto University, Kumamoto 860-0811, Japan

${ }^{2}$ Present Address: Oral Biochemistry and Molecular Biology, Department of Oral Health Science, Faculty of Dental Medicine and Graduate School of Dental Medicine, Hokkaido University, Sapporo 060-8586, Japan
}

known as the hemogenic endothelium reportedly generates hematopoietic stem cells directly [3, 7-10].

Specification of angioblasts to either arterial or venous endothelial cells is established prior to forming blood vessel structures [11-13]. The receptor tyrosine kinase EphB4 and its transmembrane ligand ephrinB2 are demonstrated to be significant factors for arteriovenous definition [14]. The binding of vascular endothelial growth factor (VEGF) to its receptor VEGFR2, also known as KDR/Flk1, induces the expression of ephrinB2 through Notch signaling in arterial-fated precursor cells [15]. The specification of venous endothelial cells appears to set as the default in the absence of Notch signaling. Moreover, it has been reported that chicken ovalbumin upstream promoter-transcription factor II (COUP-TFII), which specifically expressed in venous endothelial cells, suppresses Notch signaling, leading in maintain vein identity [16]. After that, a subpopulation of venous endothelial cells acquires the expression of prospero homeobox 1 (Prox1) transcription factors, leading to specification of lymphatic endothelial cells $[13,17,18]$. COUP-TFII directly interacts with Prox1 and also controls lymphatic cell fate [19].

The process of vascular development requires various and complicated endothelial cell angiogenic behaviors. As endothelial cells proliferate, migrate, and undergo morphological changes such as elongating and sprouting, they assemble into a solid linear mass called a vascular cord. Following this, tubulogenesis occurs through 


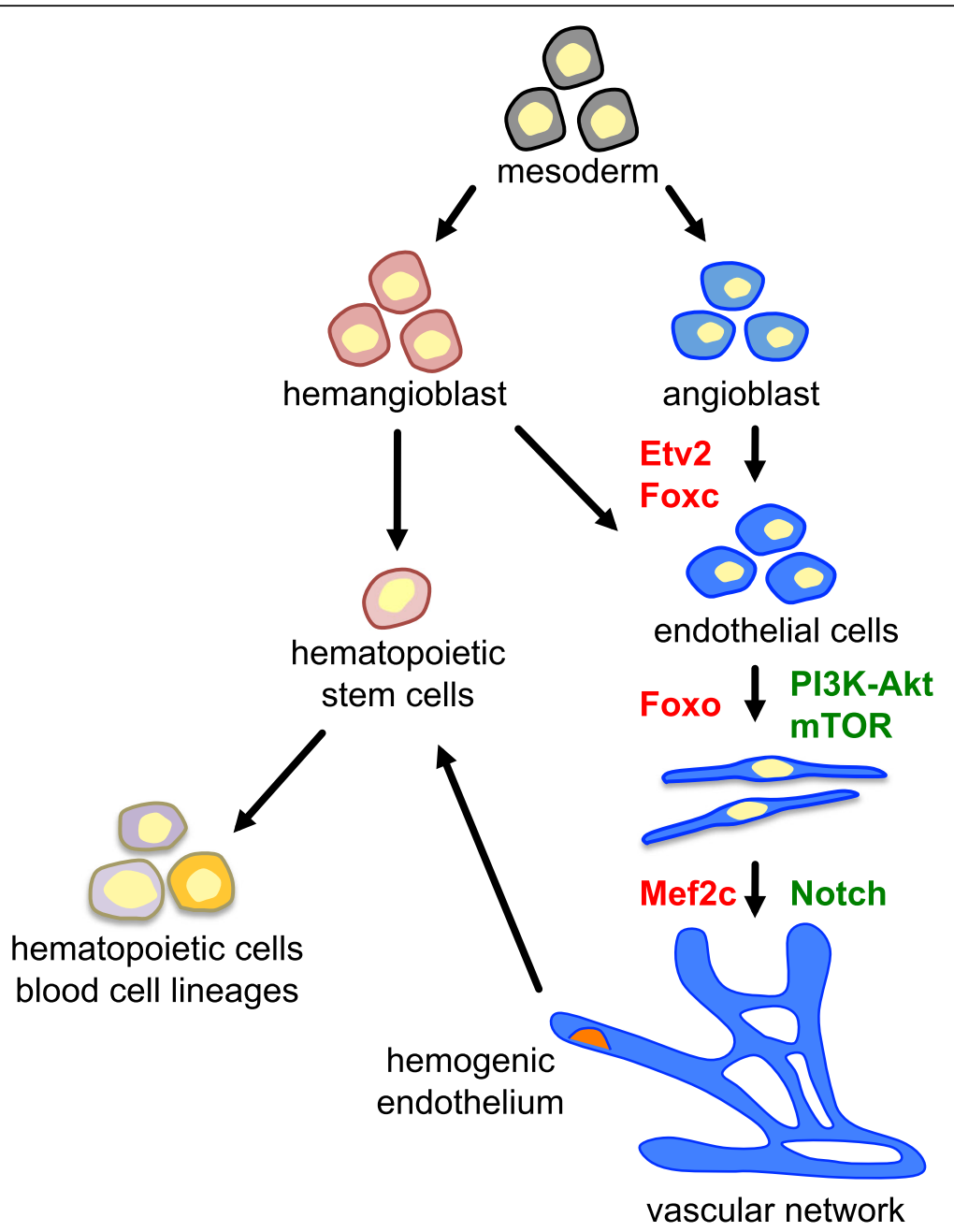

Fig. 1 Schematic model of early vascular development. Endothelial cells are derived from mesodermal precursors: angioblasts and hemangioblasts. They form vascular networks by undergoing morphological changes. Possible transcription factors (red) and signaling molecules (green) controlling each process are shown. During early vascular development, hematopoietic lineages arise from hemangioblasts or hemogenic endothelium

lumen formation at the center of the cord [20]. These processes are orchestrated at the genetic and signaling levels $[21,22]$. In this review, we concentrate on transcriptional regulators and signaling pathways required for endothelial cell regulation, especially on morphology, during vascular formation (Fig. 2).

Transcriptional regulation of endothelial cell morphology During vascularization, endothelial cells acquire specific morphological features to form vascular structures.

Although vasculature morphology has been studied widely both in vivo and in vitro, no key transcriptional signal initiating these morphological changes has yet been identified. Endothelial specification and vascular morphological change are closely related processes that occur in a partially simultaneous or sequential manner. Thus, it is unclear whether common transcriptional factors are involved in these processes or whether vascular morphology is regulated by specific factors. We discuss several transcriptional factors, including Mef2, Ets, and Forkhead, that may play important roles in early vascular development [4, 21, 22].

\section{Mef2 transcription factors}

Myocyte enhancer factor 2 (Mef2) is a member of MADS box transcription enhancer factor family. Mef2 is an important cellular development regulator in multiple cell types in muscle, vascular, neural, and immune tissues [23-25]. In vertebrates, there are four MEF2 genes: Mef2a, Mef2b, Mef2c, and Mef2d. The expression of Mef2a, Mef2c, and Mef2d can be detected in the cardiovasculature network during early embryonic development $[26,27]$ and endothelial cells in vivo and in vitro $[28,29]$, pointing to a potential role for Mef2 in vascular development. Mef2a-null mice exhibit mitochondrial deficiency in cardiac muscle and perinatal lethality [30]. 


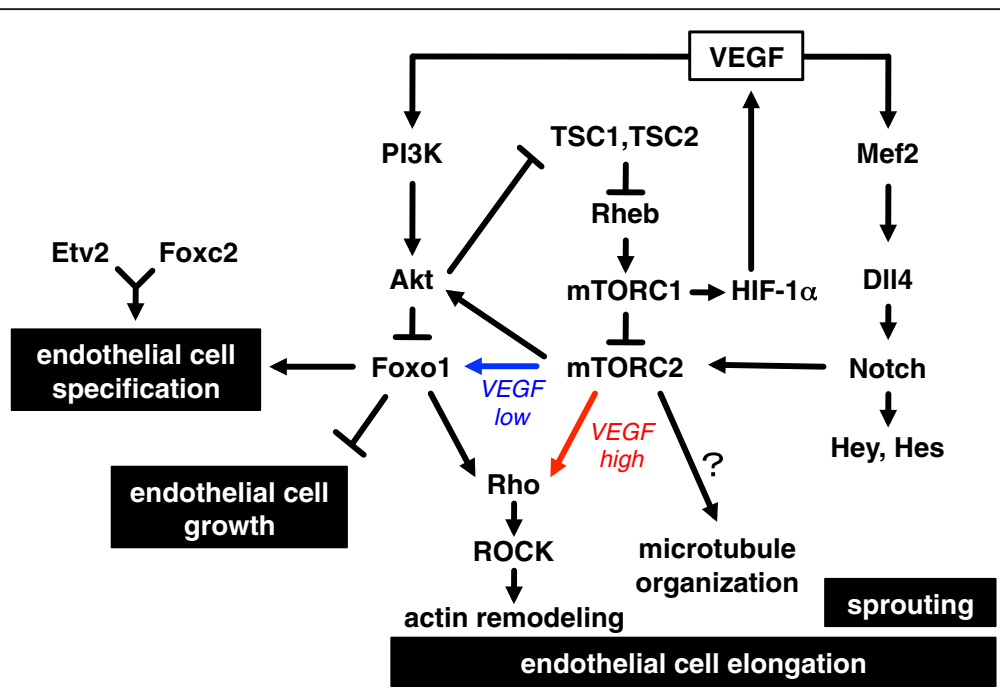

Fig. 2 Schematic model of transcription factor and signaling molecule interactions in endothelial cell functions. VEGF regulates endothelial cell functions through interaction and association with PI3K-Akt, mTOR, and Notch signaling. Foxo1-dependent (blue) and Foxo1-independent (red) pathways for endothelial cell elongation are shown. Pathway depends on environmental levels of VEGF

Mef2c-null mice show severe vascular malformations and die by E9.5 [28]. Loss of Mef2c does not affect the endothelial cell specification but inhibits smooth muscle cell differentiation, which causes the defects of vascular network. However, deletion of endothelial-specific Mef2c in mice does not result in obvious vascular defects in development [31]. Mice lacking Mef2b or Mef2d are viable and show no apparent abnormality [32, 33]. These phenotypes for each Mef2 gene deletion mutant appear to demonstrate distinct and partially overlapping functions among Mef2 members.

Mef2 factors have been demonstrated to regulate sprouting angiogenesis. In the presence of VEGF, these factors regulate the transcriptional activation of a Notch ligand Delta-like ligand 4 (Dll4) in endothelial cells [29]. Induced endothelial deletion of both Mef2a and Mef2c suppresses sprouting angiogenesis in mouse retina. In contrast, Mef2c has been shown to negatively regulate angiogenesis [34]. Mef2c overexpression inhibits VEGF-induced tube formation in HUVEC on collagen gel cultures, while Mef2 inhibition in a dominant-negative mutant enhances basal tube formation.

\section{Ets and Foxc transcription factors}

De Val et al. described a conserved endothelial cellspecific enhancer identified from the Mef2c gene [35, 36]. The enhancer contains a composite DNA binding site, referred to as the FOX:ETS motif. Etv2, also known as ER71 or Etsrp71, which is an ETS family transcription factor. Forkhead box C2 (Foxc2), also known as Mfh-1, is a member of the forkhead box (Fox) family of transcription factors. Etv2 in combination with Foxc2 binds to the FOX:ETS motif, leading to the activation of genes for endothelial specification and establishment. Endothelial gene enhancers or promoters, such as Mef2c, Flk1, Tie2, Tal1, Notch4, and VE-cadherin, contain FOX:ETS motifs and thus appear to be under the control of the combination of Etv2 and Foxc2.

Loss of Etv2 causes a complete lack of endothelial and blood cells whereby mutant mice die by E10.5 [2, 37], suggesting that Etv2 is an indispensable factor in vasculogenesis and hematopoiesis. Foxc2 knockout mice die prenatally and perinatally, with cardiovascular system, skeletal structure, and lymphatic vascular system malformations; however, major vessels remain [38, 39]. Foxc1 expression has been reported to overlap with that of Foxc2. Foxc1 knockout mice also die prenatally and perinatally, with similar abnormalities as mutants lacking Foxc2 [40-42]. Foxc1 and Foxc2 compound null mice die by E9.5 and display more severe cardiovascular system abnormalities compared with mice lacking either Foxc1 or Foxc2 [42-44]. Moreover, Foxc1 is also able to bind to the FOX:ETS motif [36]. These findings indicate redundant roles of Foxc1 and Foxc2 during vasculature development [45].

We previously demonstrated that the Mef2c enhancer with the FOX:ETS motif is activated in endothelial cell precursors derived from murine embryonic stem (ES) cells $[46,47]$. Activation is induced continuously in differentiated endothelial cells with a flat polygonal shape, and cells with an elongated shape stimulated by a high concentration of VEGF. Therefore, activation of the FOX:ETS motif may participate in endothelial cell lineage specification, but it is not necessarily connected to changes in endothelial cell morphology. 


\section{Foxo transcription factors}

The forkhead box $\mathrm{O}$ (Foxo) transcription factor family contains four members: Foxo1, Foxo3, Foxo4, and Foxo6. This family is generally associated with promoting cell cycle arrest as well as inducing apoptosis and oxidative stress resistance [48, 49]. High Foxo1 expression can be observed in developing embryonic vasculature. Foxo1-deficient mice can provide insight into the role Foxo1 plays in vascular morphology during embryonic development $[50,51]$. While Foxo1-null embryos have differentiated endothelial cells, they exhibit severe vascular defects including underdevelopment of branchial arches and malformation of dorsal aorta, thus resulting in death near embryonic days 10.5-11. This phenotype is mimicked by endothelial cell-specific deletion of Foxo1 in mice [52], suggesting that Foxo1 expression in endothelial cells is required for vascular structure formation in vivo.

ES cell-derived Foxo1-deficient endothelial cells do not exhibit cell elongation in response to VEGF [50]. They show actin-microtubule cytoskeleton disorganization and fail to interact with smooth muscle cells [53], suggesting a potential role of Foxo1 in cytoskeletal remodeling and smooth muscle cell recruitment. Conversely, Foxo1 may be required for endothelial growth control during postnatal vascular development or in mature endothelial cells. Inducible endothelial cell-specific disruption of Foxo1 enhances endothelial proliferation and leads to hyperplastic vasculature during retinal angiogenesis in mice [54]. Foxo1 appears to confer quiescence in endothelial cells by reducing metabolic activity via suppressed Myc signaling. Combined deletion of Foxo1, Foxo3, and Foxo4 in mice causes hemangiomas, which is increasing along with aging process [55]. Foxo1 overexpression suppresses migration and matrigel tube formation in human umbilical vein endothelial cells (HUVEC) [56]. Moreover, Foxo1 may bind less strongly to the FOX:ETS motif than FoxC1 or FoxC2 [36]. These findings suggest that Foxo1 may regulate multiple discrete endothelial cell functions during vascularization. Although multiple factors have been demonstrated that appear to be regulated by Foxo1, including Ang2, CXCR4, PDGF-B, and Flk1 [56], the transcriptional targets involved with changes in endothelial morphology remain unclear.

Foxo1, Foxo3, and Foxo4 have highly conserved amino acids [57]. However, Foxo3- and Foxo4-null mice are viable and outwardly normal, with no detectable vascular formation abnormalities comparable to those observed in Foxo1-null mice [50, 51]. Foxo6-null mice also develop normally and do not show any vascular malformation [58]. The redundant functions of Foxo subtypes have been demonstrated with in vitro experiments. Foxo3 induction in Foxo1-deficient endothelial cells derived from ES cells alleviates morphological abnormalities during the late, but not early, differentiation stage [59]. Foxo3 as well as Foxo1 overexpression inhibits migration and tube formation in HUVEC [56]. Foxo3 may partially overlap with Foxo1 in regulating endothelial cell functions.

\section{Signaling regulation of endothelial cell morphology}

VEGF is a well-known angiogenic factor that regulates various endothelial functions including survival, proliferation, migration, differentiation, and vascular permeability $[60,61]$. The VEGF pathway interacts and associates with multiple pathways, such as PI3K-Akt, mTOR, and Notch signaling [62, 63], and transmits signals to cells during angiogenesis.

\section{VEGF signaling}

The signaling of VEGF and VEGFR2 plays an indispensable role in vascular development as well as regulates multiple angiogenic processes, including vascular growth and homeostasis [60, 64]. Heterozygous disruption of VEGF in mice causes abnormal blood vessel formation, resulting in embryonic death by E12 [65, 66]. VEGFR2-deficient mice die by E9.5 due to underdeveloped hematopoietic and endothelial cells [67]. These experiments identify the critical function of VEGF-VEGFR2 in vascular development. VEGF binds to and activates VEGFR2, leading to activation of intracellular signals such as protein kinase $C$ (PKC), mitogen-activated protein kinase (MAPK), phosphatidyl inositol 3-kinase (PI3K)/Akt, also known as protein kinase $\mathrm{B}(\mathrm{PKB})$, and focal adhesion kinase (FAK). These signals regulate endothelial cell proliferation, migration, survival, and permeability [60]. VEGF has been reported to induce Mef2c expression and regulate endothelial cell functions such as migration or tube formation $[68,69]$.

Many studies demonstrate the important role VEGF plays in both physiological angiogenesis and pathological or therapeutic angiogenesis. Aberrant VEGF production in a tumor environment is induced through activation of hypoxia-inducible factor $1 \alpha$ (HIF- $1 \alpha)$ mostly under hypoxia and results in the formation of disorganized and leaky tumor vessels $[60,70]$. These abnormal vascular networks prevent the delivery of anti-cancer drugs to the tumor. Therefore, normalization of tumor vasculature has been proposed as a potential therapeutic strategy in cancer treatment [71-73]. VEGF has also been applied in tissue engineering to gain neovascularization due to its strong induction of angiogenesis [74, 75]. However, over-secretion of VEGF in myoblasts reportedly leads to hemangioma when transplanted into mouse muscle [76]. Although VEGF is required for vascular formation and maintenance, an appropriate level of VEGF in each environment is crucial.

We recently demonstrated that pharmacological inhibition of PI3K-Akt and mammalian target of rapamycin complex 1 (mTORC1) signaling can induce endothelial 
cell elongation without excess VEGF stimulation [47]. ES-derived endothelial cells require a low level of VEGF for growth. When stimulated by high levels of VEGF, these cells show over-growth and a shift from a flat, polygonal shape to a long, elongated shape (Fig. 3) [46, $47,59]$. However, PI3K-Akt or mTORC1 signaling inhibition also induces endothelial cell elongation in the presence of low levels of VEGF. These results indicate that PI3K-Akt and mTORC1 negatively regulate endothelial cell elongation.

\section{PI3K-Akt signaling}

PI3K-Akt signaling is activated by growth factors and angiogenic factors such as insulin, VEGF, and angiopoietin [77-79]. The serine/threonine protein kinase Akt is phosphorylated and activated by phosphoinositide-dependent kinase 1 (PDK1) when it binds to phosphatidylinositol3,4,5-trisphosphate (PIP3) produced by PI3K. Phosphatase and tensin homolog deleted on chromosome 10 (PTEN) suppresses PI3K signaling through dephosphorylation of PIP3. Activated Akt negatively or positively regulates downstream targets to control various cellular functions including cell survival, proliferation, and metabolism. PI3K-Akt signaling has been shown to increase VEGF expression by producing the HIF- $1 \alpha$ protein, thereby inducing angiogenesis [80, 81]. The binding of VEGF and VEGFR2 appears to increase mTORC1 activation through PI3K-Akt signaling, leading to endothelial cell survival and growth [77, 82, 83].

PI3K isoforms are divided into three classes: class I, class II, and class III [78, 84]. Blocking class IA PI3K signaling through general or endothelial cell-specific inactivation of p110 $\alpha$ subunits in mice results in embryonic lethality by E12.5 due to severe vascular defects including an underdeveloped vascular plexus and poorly remodeled, enlarged vessels [85]. Endothelial cell-specific loss of class IA PI3K signaling through ablation of $\mathrm{p} 85 \alpha$ and $\mathrm{p} 85 \beta$ subunits also causes embryonic lethality at E11.5 due to hemorrhaging [86]. These mice show normal phenotypes during early vasculogenesis but later show severe microvessel dilation and red blood cell congestion. General or endothelial cell-specific class II PI3K-C2 $\alpha$-deleted mice die between E10.5 and E12.5 due to vascular abnormalities, including microvessel dilation, hemorrhaging, and reduced branching [87]. These findings suggest that these signaling pathways are not involved in the initial stages of vascular development but are required for subsequent vascular remodeling and integrity.

Akt has three isoforms (Akt1, Akt2, and Akt3) that have partially overlapping and specific functions. Akt1 has been demonstrated to play a central role in angiogenesis [77] Akt1-deficient mice are viable but show reduced body weight $[88,89]$. In vascular structure, loss of Akt1 causes decreased vascularization and reduced phosphorylation of endothelial nitric-oxide synthase (eNOS) in the placenta [89]. Postnatal deletion of endothelial-specific Akt1 in mice leads to delayed angiogenesis in mouse retina [90]. Endothelial coverage and radial outgrowth are also reduced in mouse retina. These findings indicate that PI3K and Akt are essential signaling molecules in vascular development.

Foxo1 is reportedly phosphorylated by PI3K-Akt signaling then translocalized from the nucleus to the cytoplasm, which results in suppression of its transcriptional activity [91, 92]. Inhibition of PI3K-Akt signaling by LY294002 or Akt inhibitor VIII induces endothelial cell elongation in the presence of low levels of VEGF [47]. In contrast, Foxo1-deficient endothelial cells fail to respond to PI3K-Akt inhibition even in the presence of excess VEGF. These findings imply that PI3K-Akt inhibition induces endothelial cell elongation by activating Foxo1. Thus, PI3K-Akt signaling appears to negatively regulate the elongation of endothelial cells. Ola et al. reported that PI3K signaling inhibition improves vascular defects in a mouse vascular malformation caused by blocking of bone morphogenetic protein (BMP) 9/10 or Activin receptorlike kinase 1 (Alk1) [92]. Loss of BMP9/10 or Alk1 increases Akt and Foxo1 phosphorylation in endothelial

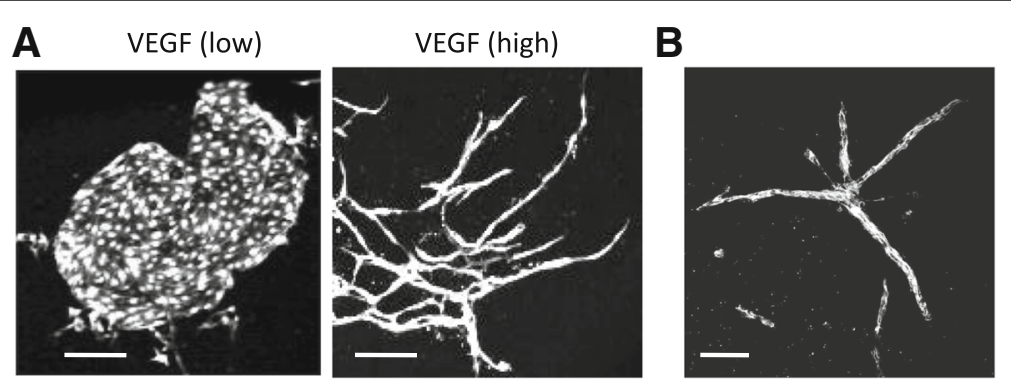

Fig. 3 Elongation of endothelial cells derived from ES cells. a In the co-culture system with OP9 stromal feeder cells, ES-derived endothelial cells form a round colony in the presence of a low level of VEGF, which produced by OP9 cells (left panel). These cells form long elongated structures, when stimulated by a high level of VEGF (right panel). Scale bar $200 \mu \mathrm{m}$. b ES-derived endothelial cells form vessel-like structures in the 3D collagen gel culture. Scale bar $100 \mu \mathrm{m}$ 
cells. These findings suggest PI3K-Akt signaling plays a key role in regulating endothelial cell morphology.

\section{mTOR signaling}

mTOR signaling is a crucial mediator in cell survival, proliferation, metabolism, and tumorigenesis [93]. mTOR is a serine/threonine protein kinase that forms two functionally distinct complexes, mTORC1 and mTORC2. The role of mTORC1 signaling in tumor angiogenesis is well understood. The GTP-bound active form of Ras homolog enriched in brain (Rheb) interacts and activates mTORC1, which drives VEGF secretion in tumor cells by inducing HIF- $1 \alpha$, promoting fragile tumor vessels $[62,77,94]$. Rheb is inactivated by tuberous sclerosis 1 (TSC1) and TSC2, which enhance conversion to the GDP-bound inactive form of Rheb due to its GAP activity. TSC2 is phosphorylated and inactivated by Akt $[95,96]$. Thus, PI3K-Akt signaling is involved in mTORC1 activation.

Phenotypic analysis highlights critical players of mTOR signaling in embryonic development using general or endothelial cell-specific knockout mice. Regulatory-associated proteins of MTOR, complex 1 (Raptor) is an essential component of mTORC1. RPTOR independent companion of MTOR, complex 2 (Rictor) is an essential component of mTORC2. Raptor-deficient mice die early in development [97]; embryos appear to show proliferation defects during the blastocyst stage. Loss of endothelial cell-specific Raptor also results in embryonic death [98]. Conversely, mice lacking Rictor display a normal phenotype until E9.5, after which they die mid-gestation, around E11.5 [97, 99]. Endothelial cell specific-loss of Rictor also leads to embryonic death around E11.5-12.5 [98, 100]. The loss of Rictor has been shown to cause reduced or delayed peripheral vascularization in mice [100]. These findings suggest that mTORC1 and mTORC2 signaling is required for fetal development and embryonic angiogenesis.

We have previously demonstrated that mTORC1 inhibition by rapamycin or everolimus induces ES cell-derived endothelial cell elongation in the presence of low levels of VEGF [47]. This elongation requires $\mathrm{mTORC} 2$ and depends upon Foxo1. mTORC1 has been reported to inhibit mTORC2 signaling by activating p70 ribosomal protein S6 kinase 1 (S6K1), which phosphorylates Rictor $[101,102]$. Therefore, the inhibition of mTORC1 may lead to endothelial cell elongation by compensating for mTORC2 signal activation. It is well known that mTORC2 signaling results in phosphorylation and deactivation of Foxo by activating Akt during regulation of cell proliferation and survival [97, 103-106]. However, Foxo1 is required to induce endothelial cell elongation during low VEGF conditions [47]. Although Foxo1 is a prevalent factor in endothelial morphology, mTORC1 inhibition in combination with high VEGF levels can induce endothelial cell elongation in a Foxo1-independent manner. Disruption of mTORC2 signaling by the genetic loss or decline of Rictor can inhibit the vascular assembly or angiogenic sprouting stimulated by VEGF in endothelial cells on matrix cultures $[98,107]$. Thus, mTORC2 signaling in association with high VEGF levels appears to drive endothelial cell elongation independently of Foxo1.

mTORC2 can control actin cytoskeleton organization, which is linked to cell morphology. Knockdown of Rictor prevents actin fiber assembly and fibroblast cell spreading [108]. mTORC2 regulates the actin cytoskeleton through Rho GTPase Rac. On the other hand, downregulation of Rictor reduces phosphorylation of protein Kinase $\mathrm{C} \alpha$ $(\mathrm{PKC} \alpha)$ and causes prominent organization of cytoplasmic actin fiber and reduced cortical actin in Hela cells [109]. Although the function of mTORC2 in actin organization may depend on cell type, these findings suggest that mTORC2 is a major factor in regulating the actin cytoskeleton. Downregulation of Rictor inhibits the actin stress fiber formation stimulated by VEGF in endothelial cells [107]. Endothelial cell elongation induced by PI3K-Akt or mTORC1 inhibition requires actin remodeling by activating Rho-ROCK signaling [46, 47]. Moreover, our recent study shows that dual inhibition of mTORC1/mTORC2 by KU0063794, but not mTORC1-specific inhibition by everolimus, remarkably impairs both actin and microtubule organization, inhibiting endothelial cell elongation [110]. The defects appear to result from disorderly microtubule distribution or stability. These findings suggest the mTOR signaling pathway is an important signaling node that modulates endothelial cell elongation by shaping the actin and microtubule cytoskeleton. Further studies are necessary to elucidate the mechanisms of mTOR signaling in endothelial cell morphological change.

\section{Notch signaling}

Four Notch receptors (Notch1, Notch2, Notch3, and Notch4), as well as five Notch transmembrane ligands of the Delta-Serrate-Lag (DSL) type, Jagged1 and 2 (Jag1 and Jag2), and Delta-like 1, 3, and 4 (Dll1, Dll3, and Dll4), are found in mammals $[63,111]$. Notch signaling is involved in multiple stages of vascular development, including proliferation, migration, and arterial-venous endothelial cell fate determination [112]. Notch signaling is initiated by interactions between the Notch receptor and its ligand, which leads to the cleavage and release of the Notch intracellular domain (NICD). The NICD translocates to the nucleus and binds to a recombination signal binding protein for immunoglobulin kappa J region (RBP-j), also known as CBF1/Igkjrb/PBPjk. They then upregulate the expression of their target genes, hairy and enhancer of split (Hes) or Hes-related with YRPW motif (Hey). Hes1 suppresses PTEN expression, resulting in PI3K-Akt signal activation [113]. Further, non-canonical Notch signaling has 
been reported to interact with $\mathrm{mTORC} 2[114,115]$. NICD regulates cell survival through the activation of Akt, depending on mTORC2.

Notch signaling, together with VEGF, controls sprouting angiogenesis through endothelial cell specification. Endothelial cells are specialized to tip cells and stalk cells in sprouting angiogenesis $[5,116,117]$. Tip cells lead and guide blood vessel sprouts, and stalk cells follow tip cells and form sprout elongation. In tip cells, VEGF signaling induces the expression of Dll4, which binds to and activates Notch signaling in neighboring stalk cells and suppresses stalk cell VEGFR expression. As tip cells expressing Dll4 receive stronger VEGF stimulation, they acquire the higher motility and sprouting activity, resulting in further angiogenesis. This Dll4-Notch signaling is antagonized in stalk cells by Jagged1, which modulates the base of emerging vessel sprouts. Notch signaling attenuation or heterozygous Dll4 deletion in mice increases the number of tip cells and enhances cell proliferation, causing excessive vessel sprouting and branching defect $[118,119]$. Thus, Notch signaling is essential in controlling angiogenic sprouting.

Loss of Notch1 in mice leads to embryonic lethality by E11.5 [120, 121], whereas Notch4-deficient mice are viable and exhibit no phenotypic defects [122]. However, deleting both Notch1 and Notch4 genes in mice causes embryonic lethality due to more severe vascular defects than Notch1 knockout mice [122]. Double-deletion mutants have normal vasculogenesis, but fail to perform vascular remodeling. This suggests a partially redundant function of Notch1 and Notch4 during vascular development. Similar findings were reported in RBP-j-deleted mice $[122,123]$. Heterozygous deletion of Dll4 in mice also causes similar vascular defects to those in Notch1 and Notch4 double-deletion mutants, although vascular remodeling defects are less severe [123]. Hey1 and Hey2 as well as Hes1 and Hes5 show subtype redundancy in vascular development. Hey1-deficient mice develop normally [124], and Hey2-deficient mice do not show apparent embryonic vessel development defects but have postnatal cardiac hypertrophy [125]. Loss of both Hey1 and Hey2 leads to embryonic death by E11.5 due to defects of vascular development $[124,126]$. In these mutants, early vasculogenesis is normal but large vessels do not form in the yolk sac and poor development of large vessels frequently occurs in the embryo, highlighting defects in vascular remodeling. Mice lacking either Hes1 or Hes5 exhibit no obvious abnormalities during vascular development, whereas general or endothelial-specific Hes1 deletion mutants on a Hes5-null background show defects in brain vascular remodeling [127].

In human arterial endothelial cells, VEGF induces Notch1 and Dll4 expression through the PI3K-Akt pathway [128]. Activation of Notch signaling using NICD or
Hes1 expression enhances network and cord formation in a three-dimensional model, whereas blocking Notch signaling using a dominant-negative form of RBP-j partially inhibits the network formation stimulated by VEGF. Moreover, Notch1 signaling is activated by fluid shear stress in human aortic endothelial cells [129]. Fluid shear stress is a biophysical trigger of morphological change in endothelial cells, although flow-induced shape is not identical to the vessel-like elongation of ES cell-derived endothelial cells in response to VEGF (Fig. 3). It has been established that fluid flow induces each endothelial cells to elongate in parallel to the direction of flow and causes actin filament alignment $[129,130]$. Reduced expression of Notch1 in vivo and in vitro has been shown to prevent endothelial cell elongation in response to flow as well as promote endothelial cell proliferation [129]. These findings suggest that Notch signaling plays an important role in modifying endothelial cell morphology.

\section{Vascular regeneration}

Transcription factors and signaling molecules required for vascular regeneration in adulthood have been reported. The expression of Etv2 is very low or absent in adult, however, its expression is upregulated in endothelial cells following ischemic injury [131]. Deletion of endothelial-specific Etv2 impairs neovascularization in mouse hindlimb ischemia model. The overexpression of Etv2 improves vessel formation after ischemia. Moreover, ischemic injury upregulates Dll4 expression in microvascular endothelial cells of normoperfused muscles [132]. Dll4 inhibition in a soluble mutant impairs blood flow recovery and neovascularization after ischemia in muscle. On the other hand, Foxo transcription factor is reported to negatively regulate postnatal neovascularization. Deleting Foxo3 gene in mice causes the enhanced reperfusion and the increased capillary density in hind limb ischemia [56]. These factors are critical for vascular formation during embryonic development, moreover, involved in positively or negatively regulate vascular regeneration following injury.

\section{Conclusion}

Comprehending the mechanisms regulating vascular structure formation is crucial to gain insight into both the physiological angiogenic process as well as diseases surrounding pathological angiogenesis. Abnormal or excessive angiogenesis is linked to increased tumor development $[60,70]$. In diabetic patients, uncontrolled formation or deficiency of vessels, known as disordered angiogenesis, contributes to mortality and disability [133]. Furthermore, establishing functional vascular networks is key for tissue and organ regeneration in tissue engineering $[74,75]$.

Transgenic lines (Table 1) or cultured models (Fig. 3) help to visualize vascular structure or cell shape, facilitating 
Table 1 Mouse phenotypes

\begin{tabular}{|c|c|c|c|}
\hline Disrupted gene & & Phenotype & References \\
\hline \multicolumn{4}{|l|}{ Mef2 transcription factors } \\
\hline Mef2a & & Perinatal death (cardiac sudden death), mitochondrial defects & {$[30]$} \\
\hline Mef2b & & Normal cardiac development & {$[32]$} \\
\hline Mef2c & & $\begin{array}{l}\text { Embryonic death by day } 9.5 \text {, cardiovascular defects, defects of } \\
\text { smooth muscle cell differentiation }\end{array}$ & {$[28]$} \\
\hline Mef2c (endothelial-specific deletion) & & Promotion of vascular growth in oxygen-induced retinopathy & [31] \\
\hline Mef2d & & Resistance to cardiac hypertrophy induced by pressure overload & [33] \\
\hline \multicolumn{4}{|l|}{ Ets and Foxc transcription factors } \\
\hline Etv2 & & $\begin{array}{l}\text { Embryonic death by day 10.5, defects of blood and vessel } \\
\text { development }\end{array}$ & {$[2,37]$} \\
\hline Etv2 (endothelial-specific deletion) & & No obvious phenotype in steady state condition & [131] \\
\hline Foxc1 & & $\begin{array}{l}\text { Prenatal and perinatal death, cardiovascular abnormalities, } \\
\text { skeletal defects }\end{array}$ & {$[40-42]$} \\
\hline Foxc2 & & $\begin{array}{l}\text { Prenatal and perinatal death, cardiovascular and lymphatic } \\
\text { abnormalities, skeletal defects }\end{array}$ & {$[38,39]$} \\
\hline Foxc1 and Foxc2 & & $\begin{array}{l}\text { Embryonic death by day } 9.5, \text { more severe defects of } \\
\text { cardiovascular and lymphatic development than Foxc1 } \\
\text { or Foxc2-null mice }\end{array}$ & $\begin{array}{l}{[41,43,} \\
44]\end{array}$ \\
\hline \multicolumn{4}{|l|}{ Foxo transcription factors } \\
\hline Foxol & & Embryonic death by day 10.5-11, vasculature defects & {$[50,51]$} \\
\hline Foxo1 (endothelial-specific deletion) & & Embryonic death by day 11 , vasculature defects & {$[52]$} \\
\hline Foxo3 & & $\begin{array}{l}\text { Age-dependent infertility, abnormality of ovarian follicular } \\
\text { development }\end{array}$ & {$[50,51]$} \\
\hline Foxo4 & & Normal & {$[50,51]$} \\
\hline Foxo6 & & Defects of memory consolidation & {$[58]$} \\
\hline \multicolumn{4}{|l|}{ VEGF signaling } \\
\hline VEGF (heterozygous deletion) & & $\begin{array}{l}\text { Embryonic death by day } 12 \text {, abnormality of vascular } \\
\text { development }\end{array}$ & {$[65,66]$} \\
\hline VEGFR2 & VEGF receptor & $\begin{array}{l}\text { Embryonic death by day 9.5, defects of hematopoietic } \\
\text { and endothelial cell development }\end{array}$ & [67] \\
\hline \multicolumn{4}{|l|}{ PI3K-Akt signaling } \\
\hline $\begin{array}{l}\text { p110a (general or endothelial-specific } \\
\text { inactivation) }\end{array}$ & $\begin{array}{l}\text { Class IA PI3K } \\
\text { subunit }\end{array}$ & Embryonic death by day 12.5 , vascular defects & {$[85]$} \\
\hline $\mathrm{p} 85 \mathrm{a}$ and $\mathrm{p} 85 \beta$ & $\begin{array}{l}\text { Class IA PI3K } \\
\text { subunit }\end{array}$ & $\begin{array}{l}\text { Embryonic death by day 11.5, vascular defects, } \\
\text { hemorrhage }\end{array}$ & {$[86]$} \\
\hline $\begin{array}{l}\text { PI3K-C2a (general or endothelial-specific } \\
\text { deletion) }\end{array}$ & $\begin{array}{l}\text { Class II PI3K } \\
\text { subunit }\end{array}$ & $\begin{array}{l}\text { Embryonic death by days } 11.5-12.5 \text {, vascular defects, } \\
\text { hemorrhage }\end{array}$ & [87] \\
\hline Akt1 & & $\begin{array}{l}\text { Growth retardation, reduction of vascularization in } \\
\text { placenta }\end{array}$ & {$[88,89]$} \\
\hline Akt1 (endothelial-specific postnatal deletion) & & Reduction of vascular development in retina & [90] \\
\hline \multicolumn{4}{|l|}{ mTOR signaling } \\
\hline Raptor & $\begin{array}{l}\text { mTORC1 } \\
\text { subunit }\end{array}$ & Embryonic death at early stages of development & [97] \\
\hline Raptor (endothelial cell-specific deletion) & & Embryonic death & [98] \\
\hline Rictor & $\begin{array}{l}\text { mTORC2 } \\
\text { subunit }\end{array}$ & $\begin{array}{l}\text { Embryonic death by day } 11.5 \text {, growth arrest, } \\
\text { placental abnormalities }\end{array}$ & {$[97,99]$} \\
\hline Rictor (endothelial cell-specific deletion) & & $\begin{array}{l}\text { Embryonic death by days } 11.5-12.5 \text {, growth retardation, } \\
\text { reduction of peripheral vascularization }\end{array}$ & {$[98,100]$} \\
\hline
\end{tabular}


Table 1 Mouse phenotypes (Continued)

\begin{tabular}{|c|c|c|c|}
\hline Disrupted gene & & Phenotype & References \\
\hline \multicolumn{4}{|l|}{ Notch signaling } \\
\hline Notch1 & Notch receptor & $\begin{array}{l}\text { Embryonic death by day 11.5, delayed and disorganized } \\
\text { somitogenesis }\end{array}$ & {$[120,121]$} \\
\hline Notch4 & Notch receptor & Normal & [122] \\
\hline Notch1 and Notch4 & & $\begin{array}{l}\text { More severe phenotype than Notch1-null mice, } \\
\text { defects of vascular remodeling }\end{array}$ & [122] \\
\hline DIl4 (heterozygous deletion) & Notch ligand & $\begin{array}{l}\text { Similar to phenotype of Notch1 and Notch4-null } \\
\text { mice, defects of vascular remodeling }\end{array}$ & [123] \\
\hline RBP-j & $\begin{array}{l}\text { Notch } \\
\text { transcriptional } \\
\text { effector }\end{array}$ & $\begin{array}{l}\text { Defects of vascular remodeling and somite } \\
\text { formation }\end{array}$ & [123] \\
\hline Hey1 & $\begin{array}{l}\text { Notch target } \\
\text { gene }\end{array}$ & Normal & [124] \\
\hline Hey2 & $\begin{array}{l}\text { Notch target } \\
\text { gene }\end{array}$ & Cardiac hypertrophy after birth & [125] \\
\hline Hey1 and Hey2 & & $\begin{array}{l}\text { Embryonic death by days } 9.5-11.5 \text {, defects of } \\
\text { vascular remodeling, hemorrhage }\end{array}$ & {$[124,126]$} \\
\hline Hes1 & $\begin{array}{l}\text { Notch target } \\
\text { gene }\end{array}$ & No obvious phenotype in vascular development & [127] \\
\hline Hes5 & $\begin{array}{l}\text { Notch target } \\
\text { gene }\end{array}$ & Normal & [127] \\
\hline $\begin{array}{l}\text { Hes1 and Hes5 (general or endothelial-specific } \\
\text { deletion of Hes1 on Hes5-null background) }\end{array}$ & & Defects of vascular remodeling in the brain & [127] \\
\hline
\end{tabular}

evaluation of vascular morphology. However, the mechanisms modulating endothelial cell morphological change are not well understood compared with endothelial cell differentiation or proliferation. This may be due to the intricate behaviors of endothelial cells and the diverse roles played by angiogenic factors. Accurately classifying endothelial cell events during vascular development is difficult, as events occur in spatially and temporally similar or related contexts. Furthermore, as described in the literature, relevant factors and signaling molecules frequently have overlapping functions or associated interactions. Consequently, it may be even more important to investigate and reveal specific molecules or mechanisms associated with endothelial cell morphological change. A deeper understanding of vascular development holds promise for developing new therapeutics regulating vascular function.

\section{Abbreviations}

Alk1: Activin receptor-like kinase 1; BMP: Bone morphogenetic protein; COUP-TFIl: Chicken ovalbumin upstream promoter-transcription factor II; DII1, DII3, and DII4: Delta-like 1, 3, and 4; DSL: Delta-Serrate-Lag; eNOS: Endothelial nitric-oxide synthase; ES cells: Embryonic stem cells; FAK: Focal adhesion kinase; Fox: Forkhead box; Hes: Hairy and enhancer of split; Hey: Hairy/ enhancer-of-split related with YRPW motif; HIF-1a: Hypoxia-inducible factor 1a; HUVEC: Human umbilical vein endothelial cells; Jag1 and Jag2: Jagged1 and 2; MADS: MCM1, Agamous, Deficiens, Serum-response factor; MAPK: Mitogen-activated protein kinase; Mef2: Myocyte enhancer factor 2; mTORC1: Mammalian target of rapamycin complex 1 or mechanistic target of rapamycin complex 1; NICD: Notch intracellular domain;

PDK1: Phosphoinositide-dependent kinase 1; PI3K: Phosphatidyl inositol 3kinase; PIP3: Phosphatidylinositol-3,4,5-trisphosphate; PKB: Protein kinase B;
PKCa: Protein Kinase Ca; Prox1: Prospero homeobox 1; PTEN: Phosphatase and tensin homolog deleted on chromosome 10; Raptor: Regulatory associated protein of MTOR, complex 1; RBP-j: Recombination signal binding protein for immunoglobulin kappa J region; Rheb: Ras homolog enriched in brain; Rictor: RPTOR independent companion of MTOR, complex 2;

S6K1: p70 ribosomal protein S6 kinase 1; TSC1: Tuberous sclerosis 1;

VEGF: Vascular endothelial growth factor

\section{Acknowledgements}

We gratefully thank the members of the Department of Cell Differentiation and the Liaison Laboratory Research Promotion Center, Institute of Molecular Embryology and Genetics, Kumamoto University, and Oral Biochemistry and Molecular Biology, Department of Oral Health Science, Faculty of Dental Medicine and Graduate School of Dental Medicine, Hokkaido University.

\section{Funding}

This work was supported by Japan Society for the Promotion of Science (grant numbers KAKENHI 24792237 and 15K11259), and the program of the Joint Usage/Research Center for Developmental Medicine, Institute of Molecular Embryology and Genetics, Kumamoto University.

\section{Authors' contributions}

$K T T$ designed the review topic. KTT and $\mathrm{MO}$ contributed to the drafting of the manuscript. Both authors read and approved the final manuscript.

Ethics approval and consent to participate

Not applicable.

Consent for publication

Not applicable.

Competing interests

The authors declare that they have no competing interests. 


\section{Publisher's Note}

Springer Nature remains neutral with regard to jurisdictional claims in published maps and institutional affiliations.

Received: 29 May 2018 Accepted: 7 August 2018

Published online: 10 September 2018

\section{References}

1. Stainier DY, Weinstein BM, Detrich HW 3rd, Zon LI, Fishman MC. Cloche, an early acting zebrafish gene, is required by both the endothelial and hematopoietic lineages. Development. 1995:121(10):3141-50.

2. Lee D, Park C, Lee H, Lugus JJ, Kim SH, Arentson E, Chung YS, Gomez G, Kyba M, Lin S, Janknecht R, Lim DS, Choi K. ER71 acts downstream of BMP, Notch, and Wnt signaling in blood and vessel progenitor specification. Cell Stem Cell. 2008;2(5):497-507.

3. Bautch VL. Stem cells and the vasculature. Nat Med. 2011;17(11):1437-43.

4. Conway EM, Collen D, Carmeliet P. Molecular mechanisms of blood vessel growth. Cardiovasc Res. 2001;49(3):507-21.

5. Ribatti D, Crivellato E. "Sprouting angiogenesis", a reappraisal. Dev Biol. 2012:372(2):157-65

6. Herbert SP, Huisken J, Kim TN, Feldman ME, Houseman BT, Wang RA, Shokat KM, Stainier DY. Arterial-venous segregation by selective cell sprouting: an alternative mode of blood vessel formation. Science. 2009;326(5950):294-8.

7. Boisset JC, van Cappellen W, Andrieu-Soler C, Galjart N, Dzierzak E, Robin C. In vivo imaging of haematopoietic cells emerging from the mouse aortic endothelium. Nature. 2010:464(7285):116-20.

8. Yokomizo T, Dzierzak E. Three-dimensional cartography of hematopoietic clusters in the vasculature of whole mouse embryos. Development. 2010; 137(21):3651-61.

9. Zovein AC, Hofmann JJ, Lynch M, French WJ, Turlo KA, Yang Y, Becker MS, Zanetta L, Dejana E, Gasson JC, Tallquist MD, Iruela-Arispe ML. Fate tracing reveals the endothelial origin of hematopoietic stem cells. Cell Stem Cell. 2008:3(6):625-36.

10. Tanzir A, Tsuji-Tamura K, Ogawa M. CXCR4 signaling negatively modulates the bipotential state of hemogenic endothelial cells derived from embryonic stem cells by attenuating the endothelial potential. Stem Cells. 2016:34(12):2814-24.

11. Zhong TP, Childs S, Leu JP, Fishman MC. Gridlock signalling pathway fashions the first embryonic artery. Nature. 2001;414(6860):216-20.

12. dela Paz NG, D'Amore PA. Arterial versus venous endothelial cells. Cell Tissue Res. 2009:335(1):5-16.

13. Kume T. Specification of arterial, venous, and lymphatic endothelial cells during embryonic development. Histol Histopathol. 2010;25(5):637-46.

14. Wang HU, Chen ZF, Anderson DJ. Molecular distinction and angiogenic interaction between embryonic arteries and veins revealed by ephrin-B2 and its receptor Eph-B4. Cell. 1998;93(5):741-53.

15. Lawson ND, Vogel AM, Weinstein BM. Sonic hedgehog and vascular endothelial growth factor act upstream of the Notch pathway during arterial endothelial differentiation. Dev Cell. 2002;3(1):127-36.

16. You LR, Lin FJ, Lee CT, DeMayo FJ, Tsai MJ, Tsai SY. Suppression of Notch signalling by the COUP-TFIl transcription factor regulates vein identity. Nature. 2005:435(7038):98-104.

17. Srinivasan RS, Dillard ME, Lagutin OV, Lin FJ, Tsai S, Tsai MJ, Samokhvalov IM, Oliver $\mathrm{G}$. Lineage tracing demonstrates the venous origin of the mammalian lymphatic vasculature. Genes Dev. 2007;21(19):2422-32.

18. Oliver G, Srinivasan RS. Endothelial cell plasticity: how to become and remain a lymphatic endothelial cell. Development. 2010;137(3):363-72.

19. Yamazaki T, Yoshimatsu Y, Morishita Y, Miyazono K, Watabe T. COUP-TFI regulates the functions of Prox 1 in lymphatic endothelial cells through direct interaction. Genes Cells. 2009;14(3):425-34.

20. Charpentier MS, Conlon FL. Cellular and molecular mechanisms underlying blood vessel lumen formation. BioEssays. 2014;36(3):251-9.

21. De Val S. Key transcriptional regulators of early vascular development. Arterioscler Thromb Vasc Biol. 2011;31(7):1469-75.

22. Park C, Kim TM, Malik AB. Transcriptional regulation of endothelial cell and vascular development. Circ Res. 2013;112(10):1380-400

23. Pon JR, Marra MA. MEF2 transcription factors: developmental regulators and emerging cancer genes. Oncotarget. 2016;7(3):2297-312.

24. Potthoff MJ, Olson EN. MEF2: a central regulator of diverse developmental programs. Development. 2007;134(23):4131-40.
25. Tirziu D, Simons M. Endothelium as master regulator of organ development and growth. Vasc Pharmacol. 2009;50(1-2):1-7.

26. Edmondson DG, Lyons GE, Martin JF, Olson EN. Mef2 gene expression marks the cardiac and skeletal muscle lineages during mouse embryogenesis. Development. 1994;120(5):1251-63.

27. Subramanian SV, Nadal-Ginard B. Early expression of the different isoforms of the myocyte enhancer factor-2 (MEF2) protein in myogenic as well as non-myogenic cell lineages during mouse embryogenesis. Mech Dev. 1996;57(1):103-12.

28. Lin Q, Lu J, Yanagisawa H, Webb R, Lyons GE, Richardson JA, Olson EN. Requirement of the MADS-box transcription factor MEF2C for vascular development. Development. 1998;125(22):4565-74.

29. Sacilotto N, Chouliaras KM, Nikitenko LL, Lu YW, Fritzsche M, Wallace MD, Nornes S, Garcia-Moreno F, Payne S, Bridges E, Liu K, Biggs D, Ratnayaka I, Herbert SP, Molnar Z, Harris AL, Davies B, Bond GL, Bou-Gharios G, Schwarz JJ, De Val S. MEF2 transcription factors are key regulators of sprouting angiogenesis. Genes Dev. 2016;30(20):2297-309.

30. Naya FJ, Black BL, Wu H, Bassel-Duby R, Richardson JA, Hill JA, Olson EN. Mitochondrial deficiency and cardiac sudden death in mice lacking the MEF2A transcription factor. Nat Med. 2002;8(11):1303-9.

31. Xu Z, Gong J, Maiti D, Vong L, Wu L, Schwarz JJ, Duh EJ. MEF2C ablation in endothelial cells reduces retinal vessel loss and suppresses pathologic retinal neovascularization in oxygen-induced retinopathy. Am J Pathol. 2012;180(6):2548-60.

32. Lin Q, Schwarz J, Bucana C, Olson EN. Control of mouse cardiac morphogenesis and myogenesis by transcription factor MEF2C. Science. 1997;276(5317):1404-7.

33. Kim Y, Phan D, van Rooij E, Wang DZ, McAnally J, Qi X, Richardson JA, Hill JA Bassel-Duby R, Olson EN. The MEF2D transcription factor mediates stressdependent cardiac remodeling in mice. J Clin Invest. 2008:118(1):124-32.

34. Sturtzel C, Testori J, Schweighofer B, Bilban M, Hofer E. The transcription factor MEF2C negatively controls angiogenic sprouting of endothelial cells depending on oxygen. PLoS One. 2014;9(7):e101521.

35. De Val S, Anderson JP, Heidt AB, Khiem D, Xu SM, Black BL. Mef2C is activated directly by Ets transcription factors through an evolutionarily conserved endothelial cell-specific enhancer. Dev Biol. 2004;275(2):424-34.

36. De Val S, Chi NC, Meadows SM, Minovitsky S, Anderson JP, Harris IS, Ehlers ML, Agarwal P, Visel A, Xu SM, Pennacchio LA, Dubchak I, Krieg PA, Stainier DY, Black BL. Combinatorial regulation of endothelial gene expression by ets and forkhead transcription factors. Cell. 2008;135(6):1053-64.

37. Ferdous A, Caprioli A, lacovino M, Martin CM, Morris J, Richardson JA, Latif S, Hammer RE, Harvey RP, Olson EN, Kyba M, Garry DJ. Nkx2-5 transactivates the Ets-related protein 71 gene and specifies an endothelial/endocardial fate in the developing embryo. Proc Natl Acad Sci U S A. 2009:106(3):814-9.

38. lida K, Koseki H, Kakinuma $H$, Kato N, Mizutani-Koseki $Y$, Ohuchi H, Yoshioka H, Noji S, Kawamura K, Kataoka Y, Ueno F, Taniguchi M, Yoshida N, Sugiyama T, Miura N. Essential roles of the winged helix transcription factor MFH-1 in aortic arch patterning and skeletogenesis. Development. 1997;124(22):4627-38

39. Petrova TV, Karpanen T, Norrmen C, Mellor R, Tamakoshi T, Finegold D, Ferrell R, Kerjaschki D, Mortimer P, Yla-Herttuala S, Miura N, Alitalo K. Defective valves and abnormal mural cell recruitment underlie lymphatic vascular failure in lymphedema distichiasis. Nat Med. 2004;10(9):974-81.

40. Kume T, Deng KY, Winfrey V, Gould DB, Walter MA, Hogan BL. The forkhead/winged helix gene Mf1 is disrupted in the pleiotropic mouse mutation congenital hydrocephalus. Cell. 1998;93(6):985-96.

41. Winnier GE, Kume T, Deng K, Rogers R, Bundy J, Raines C, Walter MA, Hogan $\mathrm{BL}$, Conway SJ. Roles for the winged helix transcription factors MF1 and MFH1 in cardiovascular development revealed by nonallelic noncomplementation of null alleles. Dev Biol. 1999;213(2):418-31.

42. Kume $T$, Jiang $H$, Topczewska JM, Hogan BL. The murine winged helix transcription factors, Foxc1 and Foxc2, are both required for cardiovascular development and somitogenesis. Genes Dev. 2001;15(18):2470-82.

43. Seo S, Fujita $H$, Nakano A, Kang M, Duarte A, Kume T. The forkhead transcription factors, Foxc1 and Foxc2, are required for arterial specification and lymphatic sprouting during vascular development. Dev Biol. 2006:294(2):458-70.

44. Seo S, Kume T. Forkhead transcription factors, Foxc1 and Foxc2, are required for the morphogenesis of the cardiac outflow tract. Dev Biol. 2006;296(2):421-36 
45. Papanicolaou KN, Izumiya Y, Walsh K. Forkhead transcription factors and cardiovascular biology. Circ Res. 2008;102(1):16-31.

46. Tsuji-Tamura K, Sakamoto H, Ogawa M. ES cell differentiation as a model to study cell biological regulation of vascular development. In: Atwood CS, ed. Embryonic stem cells: the hormonal regulation of pluripotency and embryogenesis: InTech, 2011:581-606.

47. Tsuji-Tamura K, Ogawa M. Inhibition of the PI3K/Akt and mTORC1 signaling pathways promotes the elongation of vascular endothelial cells. J Cell Sci. 2016;129:1165-78.

48. Carlsson P, Mahlapuu M. Forkhead transcription factors: key players in development and metabolism. Dev Biol. 2002;250(1):1-23.

49. Eijkelenboom A, Burgering BM. FOXOs: signalling integrators for homeostasis maintenance. Nat Rev Mol Cell Biol. 2013;14(2):83-97.

50. Furuyama T, Kitayama K, Shimoda Y, Ogawa M, Sone K, Yoshida-Araki K, Hisatsune H, Nishikawa S, Nakayama K, Nakayama K, Ikeda K, Motoyama N, Mori N. Abnormal angiogenesis in Foxo1 (Fkhr)-deficient mice. J Biol Chem. 2004;279(33):34741-9.

51. Hosaka T, Biggs WH 3rd, Tieu D, Boyer AD, Varki NM, Cavenee WK, Arden KC. Disruption of forkhead transcription factor (FOXO) family members in mice reveals their functional diversification. Proc Natl Acad Sci U S A. 2004;101(9):2975-80.

52. Dharaneeswaran H, Abid MR, Yuan L, Dupuis D, Beeler D, Spokes KC, Janes L, Sciuto T, Kang PM, Jaminet SS, Dvorak A, Grant MA, Regan ER, Aird WC. FOXO1-mediated activation of Akt plays a critical role in vascular homeostasis. Circ Res. 2014;115(2):238-51.

53. Park SH, Sakamoto H, Tsuji-Tamura K, Furuyama T, Ogawa M. Foxo1 is essential for in vitro vascular formation from embryonic stem cells. Biochem Biophys Res Commun. 2009;390(3):861-6.

54. Wilhelm K, Happel K, Eelen G, Schoors S, Oellerich MF, Lim R, Zimmermann B, Aspalter IM, Franco CA, Boettger T, Braun T, Fruttiger M, Rajewsky K, Keller C, Bruning JC, Gerhardt H, Carmeliet P, Potente M. FOXO1 couples metabolic activity and growth state in the vascular endothelium. Nature. 2016;529(7585):216-20.

55. Paik JH, Kollipara R, Chu G, Ji H, Xiao Y, Ding Z, Miao L, Tothova Z, Horner JW, Carrasco DR, Jiang S, Gilliland DG, Chin L, Wong WH, Castrillon DH, DePinho RA. FoxOs are lineage-restricted redundant tumor suppressors and regulate endothelial cell homeostasis. Cell. 2007;128(2):309-23.

56. Potente M, Urbich C, Sasaki K, Hofmann WK, Heeschen C, Aicher A, Kollipara R, DePinho RA, Zeiher AM, Dimmeler S. Involvement of Foxo transcription factors in angiogenesis and postnatal neovascularization. J Clin Invest. 2005;115(9):2382-92.

57. Obsil T, Obsilova V. Structural basis for DNA recognition by FOXO proteins. Biochim Biophys Acta. 2011;1813(11):1946-53.

58. Salih DA, Rashid AJ, Colas D, de la Torre-Ubieta L, Zhu RP, Morgan AA, Santo EE, Ucar D, Devarajan K, Cole CJ, Madison DV, Shamloo M, Butte AJ, Bonni A, Josselyn SA, Brunet A. FoxO6 regulates memory consolidation and synaptic function. Genes Dev. 2012;26(24):2780-801.

59. Matsukawa M, Sakamoto H, Kawasuji M, Furuyama T, Ogawa M. Different roles of Foxo1 and Foxo3 in the control of endothelial cell morphology. Genes Cells. 2009;14(10):1167-81.

60. Cross MJ, Claesson-Welsh L. FGF and VEGF function in angiogenesis: signalling pathways, biological responses and therapeutic inhibition. Trends Pharmacol Sci. 2001;22(4):201-7.

61. Hoeben A, Landuyt B, Highley MS, Wildiers H, Van Oosterom AT, De Bruijn EA. Vascular endothelial growth factor and angiogenesis. Pharmacol Rev. 2004;56(4):549-80.

62. Karar J, Maity A. PI3K/AKT/mTOR pathway in angiogenesis. Front Mol Neurosci. 2011;4:51.

63. Thomas JL, Baker K, Han J, Calvo C, Nurmi H, Eichmann AC, Alitalo K. Interactions between VEGFR and Notch signaling pathways in endothelial and neural cells. Cell Mol Life Sci. 2013;70(10):1779-92.

64. Cebe-Suarez S, Zehnder-Fjallman A, Ballmer-Hofer K. The role of VEGF receptors in angiogenesis; complex partnerships. Cell Mol Life Sci. 2006; 63(5):601-15.

65. Carmeliet P, Ferreira V, Breier G, Pollefeyt S, Kieckens L, Gertsenstein M, Fahrig M, Vandenhoeck A, Harpal K, Eberhardt C, Declercq C, Pawling J, Moons L, Collen D, Risau W, Nagy A. Abnormal blood vessel development and lethality in embryos lacking a single VEGF allele. Nature. 1996;380(6573):435-9.

66. Ferrara N, Carver-Moore K, Chen H, Dowd M, Lu L, O'Shea KS, PowellBraxton L, Hillan K, Moore MW. Heterozygous embryonic lethality induced by targeted inactivation of the VEGF gene. Nature. 1996;380(6573):439-42.
67. Shalaby F, Rossant J, Yamaguchi TP, Gertsenstein M, Wu XF, Breitman ML, Schuh AC. Failure of blood-island formation and vasculogenesis in Flk-1deficient mice. Nature. 1995;376(6535):62-6.

68. Maiti $D, X u Z$, Duh EJ. Vascular endothelial growth factor induces MEF2C and MEF2-dependent activity in endothelial cells. Invest Ophthalmol Vis Sci. 2008;49(8):3640-8.

69. Xu J, Cao S, Wang L, Xu R, Chen G, Xu Q. VEGF promotes the transcription of the human PRL-3 gene in HUVEC through transcription factor MEF2C. PLoS One. 2011;6(11):e27165.

70. Azzi S, Hebda JK, Gavard J. Vascular permeability and drug delivery in cancers. Front Oncol. 2013;3:211.

71. Tong YJ, Zhang M, Zou P, Guo R. Inhibiting effect of vascular endothelial growth factor (VEGF) antisense oligodeoxynucleotides on VEGF expression in U937 cell. Zhongguo Shi Yan Xue Ye Xue Za Zhi. 2004;12(2):151-3.

72. Falcon BL, Hashizume H, Koumoutsakos P, Chou J, Bready JV, Coxon A, Oliner JD, MCDonald DM. Contrasting actions of selective inhibitors of angiopoietin-1 and angiopoietin-2 on the normalization of tumor blood vessels. Am J Pathol. 2009;175(5):2159-70.

73. Carmeliet P, Jain RK. Principles and mechanisms of vessel normalization for cancer and other angiogenic diseases. Nat Rev Drug Discov. 2011;10(6):417-27.

74. Jabbarzadeh E, Starnes T, Khan YM, Jiang T, Wirtel AJ, Deng M, Lv Q, Nair LS, Doty $S B$, Laurencin CT. Induction of angiogenesis in tissue-engineered scaffolds designed for bone repair: a combined gene therapy-cell transplantation approach. Proc Natl Acad Sci U S A. 2008;105(32):11099-104.

75. Chung JC, Shum-Tim D. Neovascularization in tissue engineering. Cell. 2012;1(4):1246-60.

76. Ozawa CR, Banfi A, Glazer NL, Thurston G, Springer ML, Kraft PE, McDonald DM, Blau HM. Microenvironmental VEGF concentration, not total dose, determines a threshold between normal and aberrant angiogenesis. J Clin Invest. 2004;113(4):516-27.

77. Jiang BH, Liu LZ. PI3K/PTEN signaling in angiogenesis and tumorigenesis. Adv Cancer Res. 2009;102:19-65.

78. Chalhoub N, Baker SJ. PTEN and the PI3-kinase pathway in cancer. Annu Rev Pathol. 2009:4:127-50.

79. Gonzalez E, McGraw TE. The Akt kinases: isoform specificity in metabolism and cancer. Cell Cycle. 2009;8(16):2502-8.

80. Jiang BH, Zheng JZ, Aoki M, Vogt PK. Phosphatidylinositol 3-kinase signaling mediates angiogenesis and expression of vascular endothelial growth factor in endothelial cells. Proc Natl Acad Sci U S A. 2000;97(4):1749-53.

81. Jiang $B H$, Jiang $G$, Zheng JZ, Lu Z, Hunter T, Vogt PK. Phosphatidylinositol 3-kinase signaling controls levels of hypoxiainducible factor 1. Cell Growth Differ. 2001;12(7):363-9.

82. Gerber HP, McMurtrey A, Kowalski J, Yan M, Keyt BA, Dixit V, Ferrara N. Vascular endothelial growth factor regulates endothelial cell survival through the phosphatidylinositol 3'-kinase/Akt signal transduction pathway. Requirement for Flk-1/KDR activation. J Biol Chem. 1998;273(46):30336-43.

83. Dayanir V, Meyer RD, Lashkari K, Rahimi N. Identification of tyrosine residues in vascular endothelial growth factor receptor-2/FLK-1 involved in activation of phosphatidylinositol 3-kinase and cell proliferation. J Biol Chem. 2001;276(21):17686-92.

84. Hawkins PT, Stephens LR. PI3K signalling in inflammation. Biochim Biophys Acta. 2015;1851(6):882-97.

85. Graupera M, Guillermet-Guibert J, Foukas LC, Phng LK, Cain RJ, Salpekar A, Pearce W, Meek S, Millan J, Cutillas PR, Smith AJ, Ridley AJ, Ruhrberg C, Gerhardt H, Vanhaesebroeck B. Angiogenesis selectively requires the p110alpha isoform of PI3K to control endothelial cell migration. Nature. 2008;453(7195):662-6.

86. Yuan TL, Choi HS, Matsui A, Benes C, Lifshits E, Luo J, Frangioni JV, Cantley LC. Class $1 \mathrm{~A}$ PI3K regulates vessel integrity during development and tumorigenesis. Proc Natl Acad Sci U S A. 2008;105(28):9739-44.

87. Yoshioka K, Yoshida K, Cui H, Wakayama T, Takuwa N, Okamoto Y, Du W, Qi X, Asanuma K, Sugihara K, Aki S, Miyazawa H, Biswas K, Nagakura C, Ueno M, Iseki S, Schwartz RJ, Okamoto H, Sasaki T, Matsui O, Asano M, Adams RH, Takakura $\mathrm{N}$, Takuwa Y. Endothelial PI3K-C2alpha, a class II PI3K, has an essential role in angiogenesis and vascular barrier function. Nat Med. 2012;18(10):1560-9.

88. Chen WS, Xu PZ, Gottlob K, Chen ML, Sokol K, Shiyanova T, Roninson I, Weng W, Suzuki R, Tobe K, Kadowaki T, Hay N. Growth retardation and increased apoptosis in mice with homozygous disruption of the Akt1 gene. Genes Dev. 2001;15(17):2203-8.

89. Yang ZZ, Tschopp O, Hemmings-Mieszczak M, Feng J, Brodbeck D, Perentes E, Hemmings BA. Protein kinase B alpha/Akt1 regulates placental development and fetal growth. J Biol Chem. 2003;278(34):32124-31. 
90. Lee MY, Luciano AK, Ackah E, Rodriguez-Vita J, Bancroft TA, Eichmann A, Simons M, Kyriakides TR, Morales-Ruiz M, Sessa WC. Endothelial Akt1 mediates angiogenesis by phosphorylating multiple angiogenic substrates. Proc Natl Acad Sci U S A. 2014;111(35):12865-70.

91. Tang ED, Nunez G, Barr FG, Guan KL. Negative regulation of the forkhead transcription factor FKHR by Akt. J Biol Chem. 1999;274(24): 16741-6.

92. Ola R, Dubrac A, Han J, Zhang F, Fang JS, Larrivee B, Lee M, Urarte AA, Kraehling JR, Genet G, Hirschi KK, Sessa WC, Canals FV, Graupera M, Yan M, Young LH, Oh PS, Eichmann A. PI3 kinase inhibition improves vascular malformations in mouse models of hereditary haemorrhagic telangiectasia. Nat Commun. 2016;7:13650.

93. Kim LC, Cook RS, Chen J. mTORC1 and mTORC2 in cancer and the tumor microenvironment. Oncogene. 2017;36(16):2191-201.

94. Dodd KM, Yang J, Shen MH, Sampson JR, Tee AR. mTORC1 drives HIF1alpha and VEGF-A signalling via multiple mechanisms involving 4E-BP1, S6K1 and STAT3. Oncogene. 2015;34(17):2239-50.

95. Kwiatkowski DJ, Manning BD. Tuberous sclerosis: a GAP at the crossroads of multiple signaling pathways. Hum Mol Genet. 2005;14 Spec No. 2:R251-8.

96. Okumura N, Yoshida H, Kitagishi Y, Murakami M, Nishimura Y, Matsuda S. PI3K/AKT/PTEN signaling as a molecular target in leukemia angiogenesis. Adv Hematol. 2012;2012:843085.

97. Guertin DA, Stevens DM, Thoreen CC, Burds AA, Kalaany NY, Moffat J, Brown M, Fitzgerald KJ, Sabatini DM. Ablation in mice of the mTORC components raptor, rictor, or $\mathrm{mLST} 8$ reveals that $\mathrm{MTORC2}$ is required for signaling to Akt-FOXO and PKCalpha, but not S6K1. Dev Cell. 2006; 11(6):859-71.

98. Wang S, Amato KR, Song W, Youngblood V, Lee K, Boothby M, Brantley-Sieders DM, Chen J. Regulation of endothelial cell proliferation and vascular assembly through distinct MTORC2 signaling pathways. Mol Cell Biol. 2015;35(7):1299-313.

99. Shiota C, Woo JT, Lindner J, Shelton KD, Magnuson MA. Multiallelic disruption of the rictor gene in mice reveals that mTOR complex 2 is essential for fetal growth and viability. Dev Cell. 2006;11(4):583-9.

100. Aimi F, Georgiopoulou S, Kalus I, Lehner F, Hegglin A, Limani P, Gomes de Lima V, Ruegg MA, Hall MN, Lindenblatt N, Haas E, Battegay EJ, Humar R. Endothelial Rictor is crucial for midgestational development and sustained and extensive FGF2-induced neovascularization in the adult. Sci Rep. 2015;5:17705.

101. Julien LA, Carriere A, Moreau J, Roux PP. mTORC1-activated S6K1 phosphorylates Rictor on threonine 1135 and regulates mTORC2 signaling. Mol Cell Biol. 2010;30(4):908-21.

102. Sun J, Liu Y, Moreno S, Baudry M, Bi X. Imbalanced mechanistic target of rapamycin $\mathrm{C} 1$ and $\mathrm{C} 2$ activity in the cerebellum of Angelman syndrome mice impairs motor function. J Neurosci. 2015;35(11):4706-18.

103. Sarbassov DD, Guertin DA, Ali SM, Sabatini DM. Phosphorylation and regulation of Akt/PKB by the rictor-mTOR complex. Science. 2005; 307(5712):1098-101

104. Rini Bl, Atkins MB. Resistance to targeted therapy in renal-cell carcinoma. Lancet Oncol. 2009:10(10):992-1000.

105. Zoncu R, Efeyan A, Sabatini DM. mTOR: from growth signal integration to cancer, diabetes and ageing. Nat Rev Mol Cell Biol. 2011;12(1):21-35.

106. Song MS, Salmena L, Pandolfi PP. The functions and regulation of the PTEN tumour suppressor. Nat Rev Mol Cell Biol. 2012;13(5):283-96.

107. Farhan MA, Carmine-Simmen K, Lewis JD, Moore RB, Murray AG. Endothelial cell mTOR complex-2 regulates sprouting angiogenesis. PLoS One. 2015;10(8):e0135245.

108. Jacinto E, Loewith $R$, Schmidt A, Lin S, Ruegg MA, Hall A, Hall MN. Mammalian TOR complex 2 controls the actin cytoskeleton and is rapamycin insensitive. Nat Cell Biol. 2004;6(11):1122-8.

109. Sarbassov DD, Ali SM, Kim DH, Guertin DA, Latek RR, Erdjument-Bromage H, Tempst P, Sabatini DM. Rictor, a novel binding partner of mTOR, defines a rapamycin-insensitive and raptor-independent pathway that regulates the cytoskeleton. Curr Biol. 2004;14(14):1296-302.

110. Tsuji-Tamura K, Ogawa M. Dual inhibition of mTORC1 and mTORC2 perturbs cytoskeletal organization and impairs endothelial cell elongation. Biochem Biophys Res Commun. 2018;497(1):326-31.

111. Yavropoulou MP, Maladaki A, Yovos JG. The role of Notch and Hedgehog signaling pathways in pituitary development and pathogenesis of pituitary adenomas. Hormones (Athens). 2015;14(1):5-18.
112. Iso T, Hamamori Y, Kedes L. Notch signaling in vascular development. Arterioscler Thromb Vasc Biol. 2003;23(4):543-53.

113. Palomero T, Sulis ML, Cortina M, Real PJ, Barnes K, Ciofani M, Caparros E, Buteau J, Brown K, Perkins SL, Bhagat G, Agarwal AM, Basso G, Castillo M, Nagase S, Cordon-Cardo C, Parsons R, ZunigaPflucker JC, Dominguez M, Ferrando AA. Mutational loss of PTEN induces resistance to NOTCH1 inhibition in T-cell leukemia. Nat Med. 2007;13(10):1203-10.

114. Perumalsamy LR, Nagala M, Banerjee $P$, Sarin A. A hierarchical cascade activated by non-canonical Notch signaling and the mTOR-Rictor complex regulates neglect-induced death in mammalian cells. Cell Death Differ. 2009;16(6):879-89.

115. Crabtree JS, Singleton CS, Miele L. Notch signaling in neuroendocrine tumors. Front Oncol. 2016;6:94

116. Eilken HM, Adams RH. Dynamics of endothelial cell behavior in sprouting angiogenesis. Curr Opin Cell Biol. 2010;22(5):617-25.

117. Siekmann AF, Affolter M, Belting HG. The tip cell concept 10 years after: new players tune in for a common theme. Exp Cell Res. 2013; 319(9):1255-63.

118. Hellstrom M, Phng LK, Hofmann JJ, Wallgard E, Coultas L, Lindblom P, Alva J, Nilsson AK, Karlsson L, Gaiano N, Yoon K, Rossant J, Iruela-Arispe ML, Kalen M, Gerhardt H, Betsholtz C. DII4 signalling through Notch1 regulates formation of tip cells during angiogenesis. Nature. 2007:445(7129):776-80.

119. Suchting S, Freitas C, le Noble F, Benedito R, Breant C, Duarte A, Eichmann $A$. The Notch ligand Delta-like 4 negatively regulates endothelial tip cell formation and vessel branching. Proc Natl Acad Sci U S A. 2007;104(9):3225-30.

120. Swiatek PJ, Lindsell CE, del Amo FF, Weinmaster G, Gridley T. Notch1 is essential for postimplantation development in mice. Genes Dev. 1994;8(6):707-19.

121. Conlon RA, Reaume AG, Rossant J. Notch1 is required for the coordinate segmentation of somites. Development. 1995;121(5):1533-45.

122. Krebs $L T$, Xue $Y$, Norton $C R$, Shutter JR, Maguire $M$, Sundberg JP, Gallahan D, Closson V, Kitajewski J, Callahan R, Smith GH, Stark KL, Gridley T. Notch signaling is essential for vascular morphogenesis in mice. Genes Dev. 2000;14(11):1343-52.

123. Krebs LT, Shutter JR, Tanigaki K, Honjo T, Stark KL, Gridley T. Haploinsufficient lethality and formation of arteriovenous malformations in Notch pathway mutants. Genes Dev. 2004;18(20):2469-73.

124. Fischer A, Schumacher N, Maier M, Sendtner M, Gessler M. The Notch target genes Hey1 and Hey2 are required for embryonic vascular development. Genes Dev. 2004;18(8):901-11.

125. Gessler M, Knobeloch KP, Helisch A, Amann K, Schumacher N, Rohde E, Fischer A, Leimeister C. Mouse gridlock: no aortic coarctation or deficiency, but fatal cardiac defects in Hey2 -/- mice. Curr Biol. 2002; 12(18):1601-4.

126. Kokubo H, Miyagawa-Tomita S, Nakazawa M, Saga Y, Johnson RL. Mouse hesr1 and hesr 2 genes are redundantly required to mediate Notch signaling in the developing cardiovascular system. Dev Biol. 2005;278(2):301-9.

127. Kitagawa M, Hojo M, Imayoshi I, Goto M, Ando M, Ohtsuka T, Kageyama R, Miyamoto $\mathrm{S}$. Hes 1 and Hes5 regulate vascular remodeling and arterial specification of endothelial cells in brain vascular development. Mech Dev. 2013;130(9-10):458-66.

128. Liu ZJ, Shirakawa T, Li Y, Soma A, Oka M, Dotto GP, Fairman RM, Velazquez OC, Herlyn M. Regulation of Notch1 and Dll4 by vascular endothelial growth factor in arterial endothelial cells: implications for modulating arteriogenesis and angiogenesis. Mol Cell Biol. 2003;23(1):14-25.

129. Mack JJ, Mosqueiro TS, Archer BJ, Jones WM, Sunshine H, Faas GC, Briot A Aragon RL, Su T, Romay MC, McDonald Al, Kuo CH, Lizama CO, Lane TF, Zovein AC, Fang Y, Tarling EJ, de Aguiar Vallim TQ, Navab M, Fogelman AM, Bouchard LS, Iruela-Arispe ML. NOTCH1 is a mechanosensor in adult arteries. Nat Commun. 2017;8(1):1620

130. Katoh $\mathrm{K}$, Kano Y, Ookawara S. Role of stress fibers and focal adhesions as a mediator for mechano-signal transduction in endothelial cells in situ. Vasc Health Risk Manag. 2008;4(6):1273-82.

131. Park C, Lee TJ, Bhang SH, Liu F, Nakamura R, Oladipupo SS, Pitha-Rowe I, Capoccia B, Choi HS, Kim TM, Urao N, Ushio-Fukai M, Lee DJ, Miyoshi H, Kim BS, Lim DS, Apte RS, Ornitz DM, Choi K. Injury-mediated vascular regeneration requires endothelial ER71/ETV2. Arterioscler Thromb Vasc Biol. 2016;36(1):86-96. 
132. Caporali A, Meloni M, Vollenkle C, Bonci D, Sala-Newby GB, Addis R, Spinetti G, Losa S, Masson R, Baker AH, Agami R, le Sage C, Condorelli G, Madeddu P, Martelli F, Emanueli C. Deregulation of microRNA-503 contributes to diabetes mellitus-induced impairment of endothelial function and reparative angiogenesis after limb ischemia. Circulation. 2011;123(3):282-91.

133. Cheng R, Ma JX. Angiogenesis in diabetes and obesity. Rev Endocr Metab Disord. 2015;16(1):67-75.

- fast, convenient online submission

- thorough peer review by experienced researchers in your field

- rapid publication on acceptance

- support for research data, including large and complex data types

- gold Open Access which fosters wider collaboration and increased citations

- maximum visibility for your research: over $100 \mathrm{M}$ website views per year

At BMC, research is always in progress. 